\title{
Potent inhibition of human telomerase by U-73122
}

\author{
Yi-Jui Chen, Wei-Yun Sheng, Pei-Rong Huang \& Tzu-Chien V. Wang* \\ Department of Molecular and Cellular Biology, Chang Gung University, Kwei-San, Tao-Yuan, 333, Taiwan
}

Received 28 April 2006; accepted 14 June 2006

(C) 2006 National Science Council, Taipei

Key words: alkylating agents, cancer therapyzU-73122, $N$-ethylmaleimide, telomerase inhibitor

\begin{abstract}
Summary
Telomerase activity is repressed in normal human somatic cells, but is activated in most cancers, suggesting that telomerase may be an important target for cancer therapy. In this study, we report that U-73122, an amphiphilic alkylating agent that is commonly used as an inhibitor for phospholipase $\mathrm{C}$, is also a potent and selective inhibitor of human telomerase. The inhibition of telomerase by U-73122 was attributed primarily to the pyrrole-2,5-dione group, since its structural analog U-73343 did not inhibit telomerase. In confirmation, we observed that telomerase was inhibited by $N$-ethylmaleimide, but not $N$-ethylsuccinimide. The $\mathrm{IC}_{50}$ value of $\mathrm{U}-73122$ for the in vitro inhibition of telomerase activity is $0.2 \mu \mathrm{M}$, which is comparable to or slightly more sensitive than that for phospholipase C. The inhibitory action of U-73122 on telomerase appears to be rather selective since the presence of externally added proteins did not protect the inhibition and the $\mathrm{IC}_{50}$ values for the other enzymes tested in this study were at least an order of magnitude higher than that for telomerase. Furthermore, we demonstrate that U-73122 can inhibit telomerase in hematopoietic cancer cells. The potent and selective inhibition of telomerase by U-73122 raises the potential exploitation of this drug and other alkylating agents as telomerase inhibitor.
\end{abstract}

\section{Introduction}

Human telomerase is a specialized reverse transcriptase composed of an RNA component (hTER), a reverse transcriptase protein subunit (hTERT), and several associated proteins [1]. Telomerase directs the synthesis of telomeric repeats (TTAGGG in human) at chromosome ends using its integral RNA component as template, and is known to play a key role in maintaining telomere length and replicative senescence [2]. Normal human somatic cells undergo telomeric attrition and replicative senescence because of inadequate levels of telomerase [3, 4]. In contrast, most cancer cells have an indefinite proliferative capacity and maintain their telomere

*To whom correspondence should be addressed. Fax: +886-3-211-8700; Tel.: +886-3-211-8147; E-mail: tcvwg (a) mail.cgu.edu.tw length by up-regulating telomerase activity $[5,6]$. The specific expression of telomerase in most cancers raises the potential application of targeting telomerase for cancer therapy. Various strategies of telomerase-based therapeutics have been explored in the past decade including: vaccines targeting hTERT peptides for immunotherapy [7, 8], gene-therapy using hTERT-promoter driven expression of suicide genes [9, 10], and inhibition of telomerase activity [11-13]. The benefits and disadvantages of these different approaches have been reviewed [11-15].

In the search of inhibitors for telomerase, we have identified protein kinase C (PKC) inhibitors could inhibit telomerase activity in nasopharyngeal cancer cells [16], which was subsequently shown to inhibit phosphorylation of telomerase proteins and thus inactivated the enzyme activity of telomerase $[17,18]$. PKC-dependent activity was also known 
to be required in the expression of telomerase activity in activated $T$ lymphocytes $[19,20]$. In this case, PKC activity was shown to be required both for the induction of $h T E R T$ expression and for the post-transcriptional control of telomerase enzyme activity [21]. To further understand the role of PKC-dependent signaling in the expression of telomerase, we have employed U-73122 [22] as an inhibitor for phosphoinositide-specific phospholipase C (PLC) to examine the role of PLC, an up-stream effector of $\mathrm{PKC}$, in the expression of telomerase activity. Much to our surprise, however, we found that this drug also inactivated the enzyme activity of telomerase in the cell extracts. In this work, the mechanism of telomerase inhibition by $\mathrm{U}-73122$ as well as its potential application as telomerase inhibitor was examined.

\section{Materials and methods}

\section{Chemicals, enzymes, and oligonucleotides}

Fetal bovine serum (FBS), Superscript III reverse transcriptase, TRIzol reagent, and antibiotics were from Gibco-BRL. U-73122, U-73343 (Figure 1) and RNase inhibitor were purchased from CalBiochem Co.. Taq DNA polymerase was from ABgene, Surrey, UK. Caspase 3 was kindly supplied by Dr. J. S. Yu. N-ethylsuccinimide (NES) was purchased from TCI America. Gel electrophoresis reagents were from Bio-Rad. All other chemicals were from Sigma Chemical Co.. The sequence and source of TS, $\mathrm{CX}_{2}$, biotinylated $\mathrm{TS}$ and digoxigeninated $\mathrm{CX}_{2}$ oligonucleotides were previously described [18, 23].

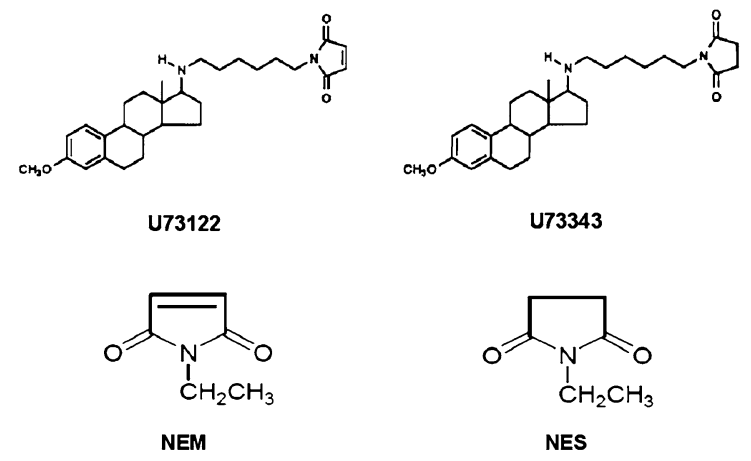

Figure 1. Structures of U-73122, U-73343, NEM, and NES.

\section{Cell culture}

Acute $\mathrm{T}$ cell leukemia-derived Jurkat cells and promyelocytic leukemia HL60 cells were cultured in RPMI medium 1640 containing $10 \%$ FBS, $2 \mathrm{mM}$ L-glutamine, and antibiotics $(100 \mathrm{U} / \mathrm{ml}$ penicillin, $100 \mathrm{U} / \mathrm{ml}$ streptomycin and $0.25 \mu \mathrm{g} / \mathrm{ml}$ amphotericin B). The peripheral blood lymphocytes (PBL) were isolated and cultured as previously described [21]. Cells were grown at $37^{\circ} \mathrm{C}$ in a humidified incubator containing $5 \% \mathrm{CO}_{2}$. Viability of cells treated with drugs was determined by staining with trypan blue.

\section{Cell extracts}

The cell extracts used for determining telomerase activity were prepared as previously described [21]. The cell extracts used for determining glucose-6-phosphate dehydrogenase (G6PD) activity were prepared by suspending the cells in G-buffer $[50 \mathrm{mM}$ Tris-HCl, pH 7.4, $150 \mathrm{mM}$ $\mathrm{NaCl}, 1 \mathrm{mM}$ EDTA, $1 \mathrm{mM} \mathrm{NaF}, 1 \% \mathrm{NP}-40$, and $0.5 \%$ sodium deoxycholate] and sonicated on ice to disrupt the cells. After centrifuging at $20,000 \mathrm{~g}$ for $15 \mathrm{~min}$ at $4{ }^{\circ} \mathrm{C}$, the supernatants were transferred to fresh tubes and used as the cell extracts for G6PD activity assay. The protein concentrations were determined using Coomassie protein assay reagent (Bio-Rad).

\section{Assays for telomerase, caspase 3, G6PD and Taq} DNA polymerase

Telomerase activity was assayed by conventional telomeric repeat amplification protocol (TRAP) [5] or a PCR-based enzyme immuno assay as previously described [23]. The effect of U-73122 and $N$-ethylmaleimide (NEM) on the activity of telomerase and Tag DNA polymerase was determined as previously described [24]. The effect of U-73122 and NEM on the activity of caspase- 3 was determined as follows. In brief, caspase- 3 was incubated in the presence or absence of drug at $25^{\circ} \mathrm{C}$ for $30 \mathrm{~min}$. After incubation, the treated samples were added to a reaction buffer containing $100 \mathrm{mM} \mathrm{NaCl}, 50 \mathrm{mM}$ HEPES (pH 7.4), $1 \mathrm{mM}$ EDTA, $10 \%$ glycerol, $0.1 \%$ CHAPS, and $0.33 \mathrm{mM}$ Ac-DEVD- $p$ NA. The protease activity of caspase 3 was determined at $37^{\circ} \mathrm{C}$ by monitoring the kinetics of absorbance at $405 \mathrm{~nm}$ in a 
spectrophotometer (Molecular Devices SPECTRAmax M2). The effect of U-73122 and NEM on the activity of G6PD in the cell extract was determined as follows. In brief, $50 \mu \mathrm{g}$ of extract protein was incubated in the presence or absence of drug in $0.9 \mathrm{ml} \mathrm{H}_{2} \mathrm{O}$ at $25{ }^{\circ} \mathrm{C}$ for $30 \mathrm{~min}$. After incubation, $100 \mu \mathrm{l}$ of reaction buffer containing $0.5 \mathrm{M}$ Tris- $\mathrm{HCl}, \mathrm{pH} 7.8,0.5 \mathrm{M} \mathrm{MgCl}_{2}, 40 \mathrm{mM}$ NADP and $40 \mathrm{mM}$ glucose-6-phosphate was added to the treated samples. The reaction mixtures were then placed at $37^{\circ} \mathrm{C}$ in a spectrophotometer (Beckman Coulter DU800) to monitor the kinetics of absorbance at $340 \mathrm{~nm}$. The effect of U-73122 and NEM on the enzyme activity was calculated by dividing the enzyme activity detected in the presence of drug by the enzyme activity detected in the absence of drug and expressed as percent relative activity.

\section{Results}

In vitro inhibition of telomerase by $U-73122$ and related compounds

To determine the part of U-73122 structure that is responsible for the inhibition of telomerase activity in vitro, we examined whether or not U-73343 (Figure 1), a structural analog of U-73122, may inhibit telomerase. The cell extracts from telomerase-positive Jurkat cells were treated with U-73122 or U-73343 at $25^{\circ} \mathrm{C}$ before assaying for telomerase activity. As shown in Figure 2, the telomerase activity was inhibited by U-73122 in a concentration-dependent manner while no detectable inhibition of telomerase activity was observed by U-73343. Similar results were also obtained with the cell extracts obtained from other telomerase-positive cancer cells such as HL60, or NPC-076 (data not shown). Delayed addition of $\mathrm{U}-73122(4 \mu \mathrm{M})$ after the telomerase extension of TS primer no longer inhibited the telomerase activity as assayed by TRAP (data not shown), indicating that the observed inhibition is at the step of telomerase extension of TS primer. Since the only difference in the structures of U-73122 and U-73343 is located at the pyrrole ring, it suggests that the inhibitory effect was attributed to the presence of $3^{\prime} 4^{\prime}$-double bond in the pyrrole-2,5-dione of U-73122. To test this postulate, we examined the effect of NEM and
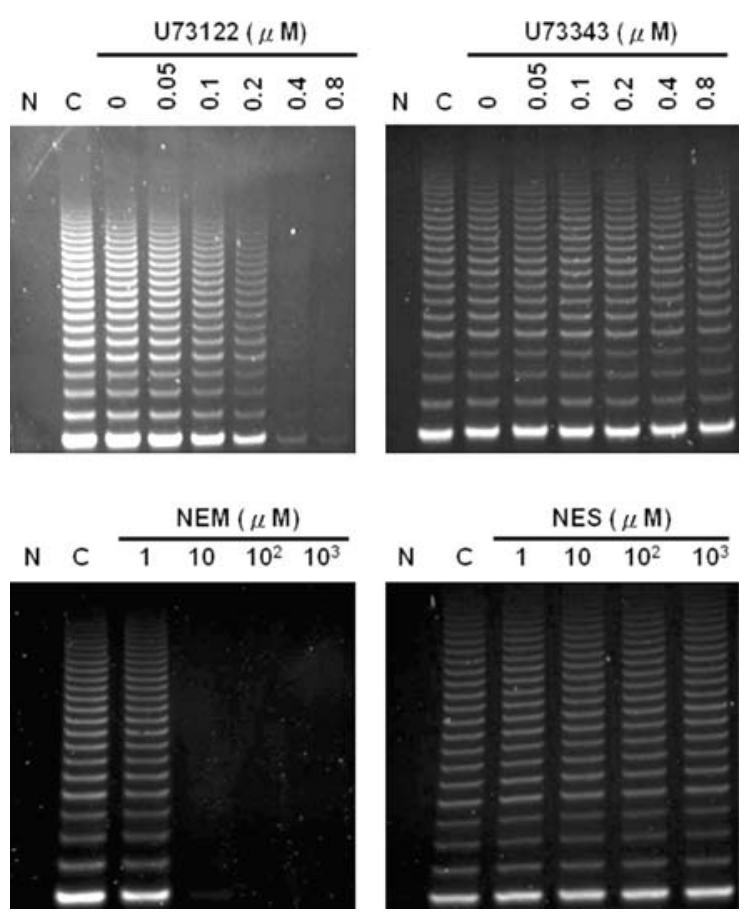

Figure 2. Effect of U-73122, U-73343, NEM, and NES on the telomerase activity in vitro. The cell extracts of Jurkat cells were incubated with different concentrations of U-73122, U-73343, NEM, and NES at $25{ }^{\circ} \mathrm{C}$ for $30 \mathrm{~min}$. The telomerase activity was then assayed by TRAP as described in Materials and Methods. Lanes $\mathrm{N}$ and $\mathrm{C}$ are negative and positive controls for the assay.

NES on the telomerase activity in vitro. As shown in Figure 2, telomerase activity was completely inhibited by $10 \mu \mathrm{M}$ of NEM, while no detectable inhibition of telomerase activity by NES was observed.

Mechanism and selectivity of telomerase inhibition by $U-73122$ and NEM

U-73122 and NEM are sulfhydryl alkylating agents that are known to inhibit many enzymes. It is likely that these drugs inactivate telomerase by alkylating the cysteine residues of telomerase proteins. To test this postulate, we examined the effect of dithiothreitol (DTT) on the protection of telomerase from inhibition by these drugs. As shown in Figure 3, the presence of $1 \mu \mathrm{M}$ DTT fully protects the inhibitory effects by U-73122, while $10 \mu \mathrm{M}$ DTT is required to protect the telomerase inhibition by NEM. These results suggest that the cysteine residues of telomerase 


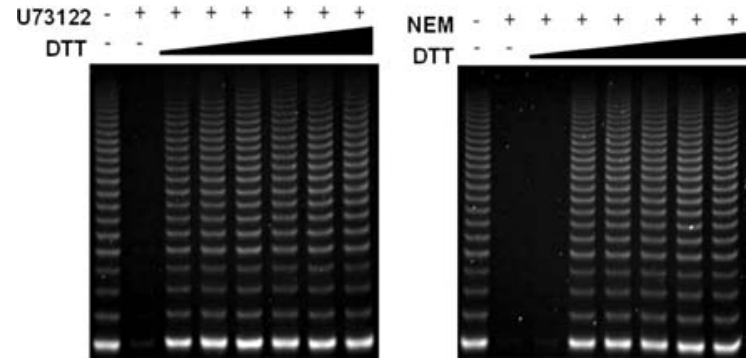

Figure 3. Protection of telomerase inhibition by DTT. The cell extracts of Jurkat cells were incubated with $0.4 \mu \mathrm{M}$ of $\mathrm{U}-73122$ or $10 \mu \mathrm{M}$ of NEM in the presence of increasing concentrations of DTT $(1-1000 \mu \mathrm{M})$ at $25^{\circ} \mathrm{C}$ for $30 \mathrm{~min}$. The telomerase activity was then assayed by TRAP as described in Materials and Methods.

proteins are the likely targets for the inhibitory action of these drugs.

Since U-73122 and NEM are known to inhibit many enzymes, it raises the question whether or not the inhibition of telomerase by these drugs is selective? A literature survey of the effective concentrations of NEM for inhibiting enzymes reveals that it usually requires $\mathrm{mM}$ concentrations of NEM to inhibit the activities of many enzymes. For examples, the inhibition of NADP-dependent isocitrate dehydrogenase [25], DNA polymerase $\alpha$ [26], DNA polymerase II [27], and RNase $\mathrm{H}$ of HIV-1 [28, 29] requires $0.6-10 \mathrm{mM}$ of NEM. In fact, some enzymes such as DNA polymerase I, RNA polymerase II and polymerase $\beta$ were not affected by NEM at these concentrations at all. Therefore, the complete inactivation of telomerase activity by $10 \mu \mathrm{M}$ of NEM would suggest that telomerase is a rather sensitive target of NEM. Similarly, U-73122 had been previously reported to have no inhibitory effect on protein kinase $\mathrm{C}$ and phospholipase $\mathrm{A}_{2}$ at 3 and $50 \mu \mathrm{M}$, respectively $[30,31]$. The efficient inhibition of telomerase in vitro by submicromolar concentrations of U-73122 (Figure 2) is comparable to that for inhibiting PLC-dependent processes [22, 30, 31], indicating that telomerase and PLC is equally sensitive to inhibition by U-73122. To validate the selective inhibition of telomerase by these drugs, the effects of U-73122 and NEM on the enzyme activity of telomerase, caspase 3, G6PD and Tag DNA polymerase were compared. As shown in Figure $4 \mathrm{~A}$, the $\mathrm{IC}_{50}$ values of U-73122 were $0.2 \mu \mathrm{M}$ for telomerase, $5.5 \mu \mathrm{M}$ for caspase 3, $10 \mu \mathrm{M}$ for G6PD, and $60 \mu \mathrm{M}$ for Taq DNA polymerase, indicating that telomerase is at least an order of magnitude more sensitive to inhibition than the other enzymes tested. Similarly, IC $_{50}$ values of NEM were $2 \mu \mathrm{M}$ for telomerase, which was considerably less than the values of $6 \mu \mathrm{M}$ for caspase 3, $20 \mu \mathrm{M}$ for G6PD and $2 \mathrm{mM}$ for Taq DNA polymerase (Figure 4B). Finally, to confirm the selective inhibition of telomerase by these drugs, the effect of externally added protein on the protection of telomerase activity was also examined. No detectable protection of telomerase activity was observed by the externally added BSA (Figure 4C). Together, these results indicate that telomerase is a rather selective target for the inhibition by U-73122 and NEM.

\section{U-73122 and NEM inhibit telomerase in hematopoietic cancer cells}

The selective inhibition of telomerase in vitro suggests that U-73122 and NEM may be used as telomerase inhibitors for cancer cells. The effects of these two drugs on the telomerase activity and viability of two hematopoietic cancer cells (Jurakat and HL60) were examined. A 30-min exposure of these cells to different concentrations of U-73122 and NEM revealed that $\mathrm{U}-73122$ at $4 \mu \mathrm{M}$ and NEM at $70-100 \mu \mathrm{M}$ resulted in a complete inactivation of telomerase activity in the treated cells (Figure 5). Prolonged treatment of these cells at reduced U-73122 concentrations (less than $1 \mu \mathrm{M}$ ) had no detectable inhibition of telomerase and most of the treated cells remained viable (data not shown). Prolonged treatment of these cells at reduced NEM concentrations, on the other hand, revealed that 5 to $7 \mu \mathrm{M}$ of NEM were effective in inhibiting telomerase of the treated cells after $24 \mathrm{~h}$ (Figure 6) and was accompanied with considerable cytotoxicity. The cytotoxic effects of U-73122 and NEM on the viability of Jurkat cells and normal PBL are summarized in Table 1. The normal PBL was the more resistant to the cytotoxic effects of these drugs as compared to Jurkat cells.

\section{Discussion}

U-73122 was synthesized as an amphiphilic alkylating agent that might be expected to partition into biomembranes and interfere with enzymes that act on membrane lipids [30]. Studies on the 
(A)

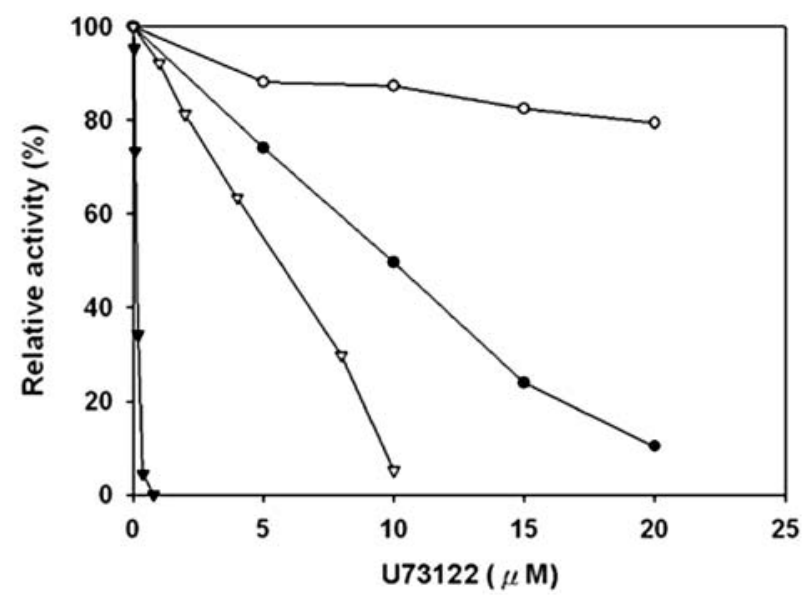

(B)
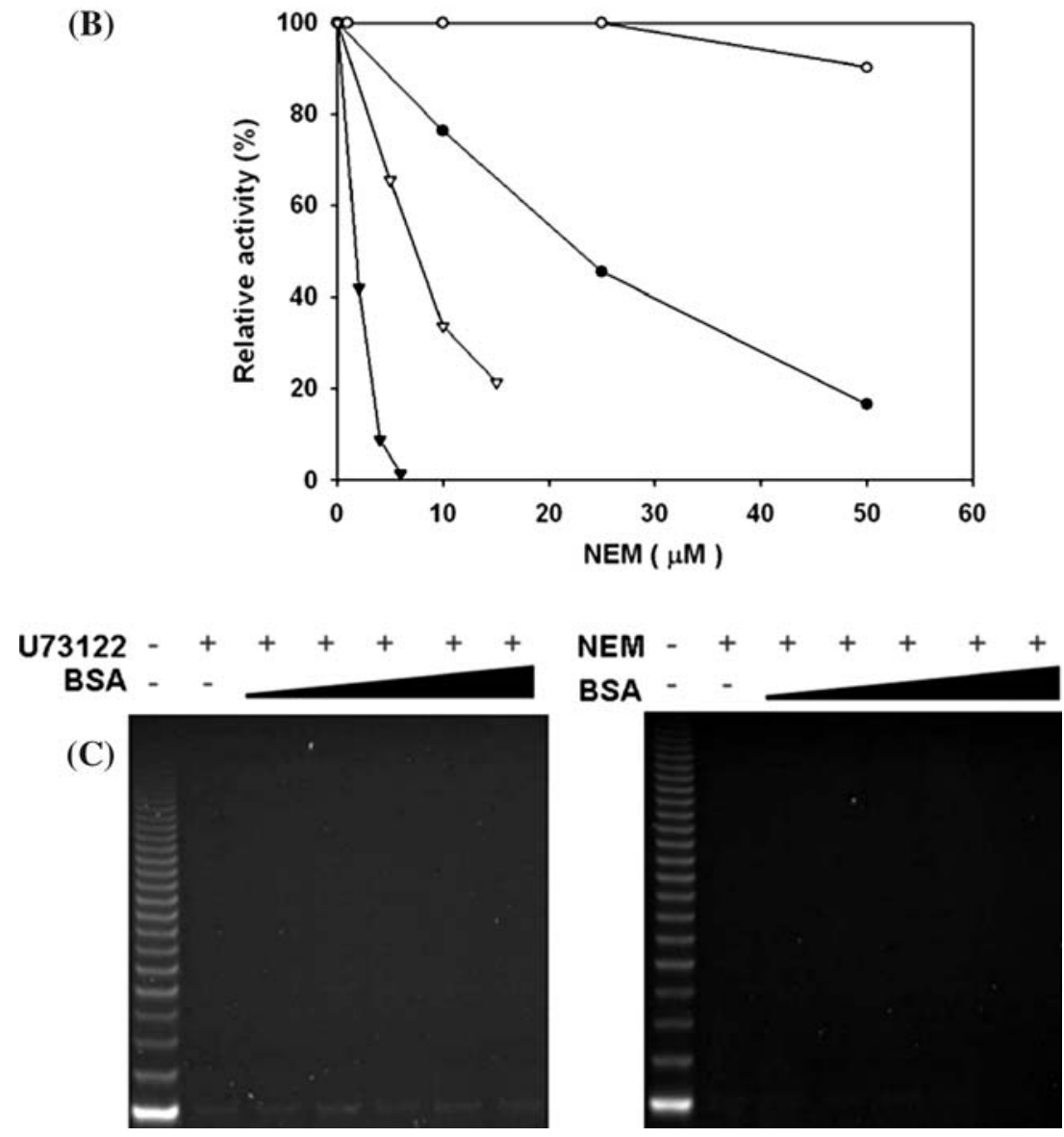

Figure 4. Selective inhibition of telomerase by U-73122 and NEM in vitro. The effects of U-73122 (panel A) and NEM (panel B) on the enzyme activity of telomerase, caspase 3, G6PD, and Taq DNA polymerase were determined as described in the Materials and Methods. The data points at higher drug concentrations for Taq DNA polymerase were omitted for clarity. Symbols: (v) telomerase; $(\nabla)$ caspase $3 ;(\bullet)$ G6PD; and (०) Tag DNA polymerase. In Panel C, the cell extracts of Jurkat cells were incubated with $0.4 \mu \mathrm{M}$ U-73122 or $10 \mu \mathrm{M} \mathrm{NEM}$ in the presence of BSA $(10-200 \mu \mathrm{g} / \mathrm{ml})$ at $25^{\circ} \mathrm{C}$ for $30 \mathrm{~min}$ before assaying for telomerase activity by TRAP. 


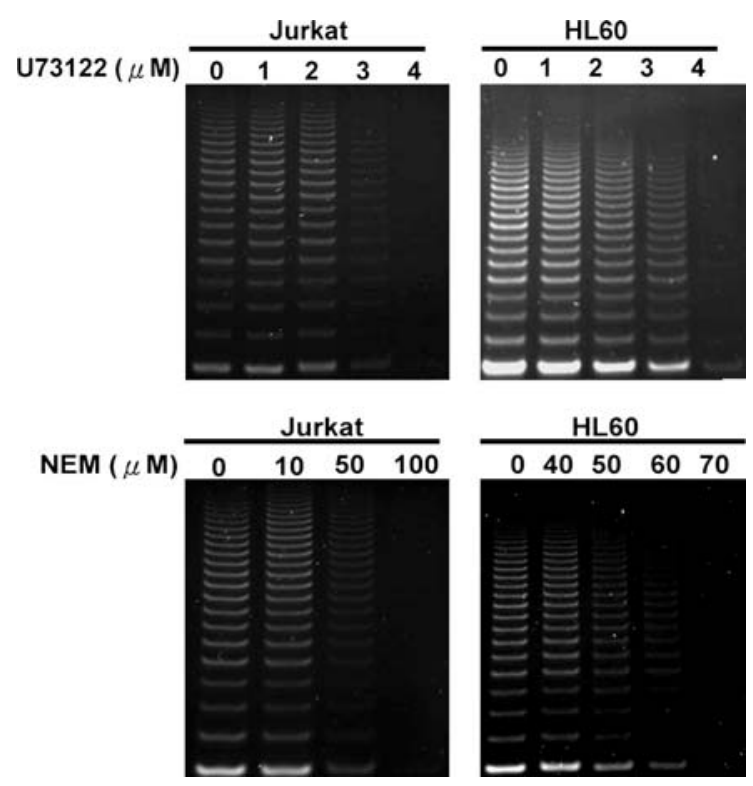

Figure 5. Effect of 30-min exposure to U-73122 and NEM on the telomerase activity of Jurkat and HL60 cells. Jurkat and HL60 cells were treated with U-73122 or NEM at $37{ }^{\circ} \mathrm{C}$ for $30 \mathrm{~min}$. Cell extracts were prepared from the treated cells, and assayed for telomerase activity as described in Materials and Methods.

action of this drug in a variety of cell types indicate that U-73122 inhibits PI-PLC-dependent processes $[22,30]$, although there is no data to preclude the possibility that U-73122 may interfere with other cellular processes. In this work, we have shown for the first time that U-73122 can inhibit human telomerase in vitro and in vivo. Structure-activity analysis indicates that the maleimide group of U-73122 is essential for the inhibitory effect. Indeed, NEM was also found to effectively inhibit

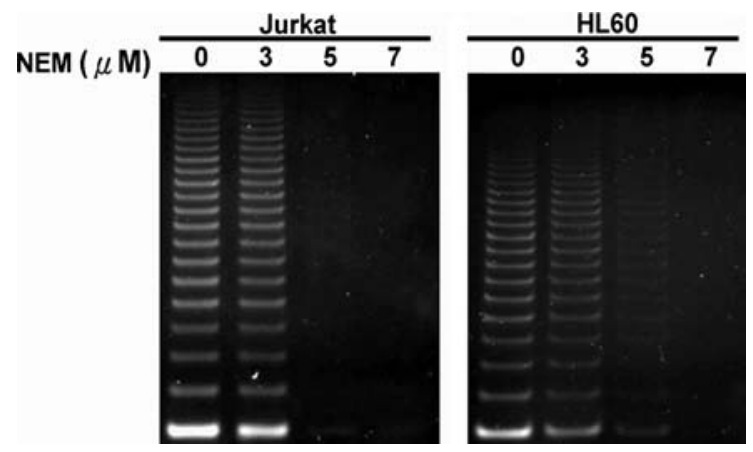

Figure 6. Effect of $24 \mathrm{~h}$ exposure to NEM on the telomerase activity of Jurkat and HL60 cells. Jurkat and HL60 cells were treated with NEM at $37^{\circ} \mathrm{C}$ for $24 \mathrm{~h}$. Cell extracts were prepared from the treated cells, and assayed for telomerase activity as described in Materials and Methods. telomerase, albeit at an order of higher concentrations than that of U-73122. Although the other $\mathrm{N}$-substituted maleimides had not been tested in the present study, the greater inhibitory effect by U-73122 suggests that $\mathrm{N}$-substituted side chain and/or group also plays a role in the inhibitory action of these maleimides on telomerase. It is likely that these maleimides act by direct alkylation of telomerase proteins, since the inhibitory effect of U-73122 and NEM can be protected by the presence of thiol-containing compounds such as DTT (Figure 3).

The inhibitory action of U-73122 on telomerase appears to be selective. The $\mathrm{IC}_{50}$ for the in vitro inactivation of telomerase by $\mathrm{U}-73122$ is $0.2 \mu \mathrm{M}$, which is considerably lower than the values for inactivating caspase 3, G6PD and Taq DNA polymerase (Figure 4). Together with the fact that the presence of externally added BSA did not exert any protection on the telomerase inhibition by U-73122 (Figure 4C), these results indicate that $\mathrm{U}-73122$ is a rather selective inhibitor for telomerase. Indeed, the concentrations of U-73122 that are required for the in vitro and in vivo inhibition of telomerase are comparable to that required for inhibiting PLC or PLC-dependent processes [30, 31] a target thought to be specific for U-73122. Therefore, when U-73122 is being used at submicromolar concentrations to inhibit PLC-dependent processes, at least a part of the biological effects produced by this drug may be attributed to the inhibition of telomerase.

The selective inactivation of telomerase by U-73122 and NEM raises the possibility that these drugs may be used as telomerase inhibitor for cancer therapy. Inhibition of telomerase in cancer cells is anticipated to result in the erosion of telomeres and ultimately leading to growth arrest, senescence or cell death. Indeed, inhibition of telomerase had been shown to limit the growth of cancer cells in culture after extended treatment [32-34], although rapid inhibition of cancer cell growth had also been observed [35]. In this work, we have examined the effects of these drugs on two hematopoietic cancer cells, Jurkat and HL60. While the telomerase activity may be inhibited by $\mathrm{U}-73122$ at $4 \mu \mathrm{M}$ or NEM at $70-100 \mu \mathrm{M}$ (Figure 5), a majority of the treated cells were not viable after $24 \mathrm{~h}$, however. The acute cytotoxic effects of these drugs were largely due to apoptosis (data not shown). To explore the possibility that 
Table 1. Effects of U-73122 and NEM on viability of PBL and Jurkat cells.

\begin{tabular}{|c|c|c|c|c|c|c|c|c|c|c|}
\hline \multirow[t]{3}{*}{ Type of cells } & \multirow[t]{3}{*}{ Treatment time (h) } & \multicolumn{9}{|c|}{ Viability (\%) } \\
\hline & & \multicolumn{5}{|c|}{$\mathrm{U}-73122(\mu \mathrm{M})$} & \multicolumn{4}{|c|}{$\operatorname{NEM}(\mu \mathrm{M})$} \\
\hline & & 0 & 1 & 2 & 3 & 4 & 0 & 3 & 5 & 7 \\
\hline \multirow[t]{2}{*}{ Jurkat } & 24 & 100 & 92.6 & 45.3 & 10.9 & 0.8 & 100 & 79.0 & 3.4 & 1.9 \\
\hline & 48 & 100 & 60.0 & 24.2 & 5.1 & 0.4 & 100 & 62.2 & 1.7 & 2.0 \\
\hline \multirow[t]{2}{*}{ PBL } & 24 & 100 & 94.2 & 51.5 & 40.2 & 30.3 & 100 & 89 & 82.8 & 79 \\
\hline & 48 & 100 & 86.1 & 43.6 & 30.6 & 24.2 & 100 & 87 & 73.4 & 65.5 \\
\hline
\end{tabular}

such a cytotoxic effect may be selective for telomerase-positive cancer cells as observed by $\mathrm{Li}$ et al. [35], we have compared the cytotoxic effects of these drugs on Jurkat and normal PBL. As shown in Table 1, although the normal lymphocytes were more resistant (about 2-fold) than the Jurkat cells, the cytotoxic effects of these drugs do not appear to be selective only for the cancer cells.

At present, it is not known why telomerase is selectively targeted for the inhibition by U-73122. In this regard, it is interesting to note that telomerase is also sensitive to the inhibition by another alkylating agent, helenalin [24], suggesting that telomerase is a sensitive target by many alkylating agents. Therefore, exploration of alkylating agents with greater selectivity for telomerase may offer as an alternative approach to develop telomerase inhibitor for anti-cancer therapy.

\section{Acknowledgements}

Supported by Chang Gung Medical Research Grant CMRPD 140041, and National Science Council Research Grant NSC 93-2311-B182-003 of Taiwan.

\section{References}

1. Cong Y.S., Wright W.E. and Shay J.W., Human telomerase and its regulation. Microbiol. Mol. Biol. Rev. 66: 407$25,2002$.

2. Blackburn E.H., Telomerases. Annu. Rev. Biochem. 61: 113-129, 1992.

3. Harley C.B., Futcher A.B. and Greider C.W., Telomeres shorten during ageing of human fibroblasts. Nature 345: 458-460, 1990.

4. Wright W.E. and Shay J.W., Cellular senescence as a tumor-protection mechanism: the essential role of counting. Curr. Opin. Genet. Dev. 11: 98-103, 2001.
5. Kim N.W., Piatyszek M.A., Prowse K.R., Harley C.B., West M.D., Ho P.L., Coviello G.M., Wright W.E., Weinrich S.L. and Shay J.W., Specific association of human telomerase activity with immortal cells and cancer. Science 266: 2011-2015, 1994.

6. Shay J.W. and Bacchetti S., A survey of telomerase activity in human cancer. Eur. J. Cancer 33: 787-791, 1997.

7. Vonderheide R.H., Telomerase as a universal tumor-associated antigen for cancer immunotherapy. Oncogene 21: 674 679, 2002.

8. Vonderheide R.H., Domchek S.M., Schultze J.L., George D.J., Hoar K.M., Chen D.Y., Stephans K.F., Masutomi K., Loda M., Xia Z., Anderson K.S., Hahn W.C. and Nadler L.M., Vaccination of cancer patients against telomerase induces functional antitumor CD8 + T lymphocytes. Clin. Cancer Res. 10: 828-839, 2004.

9. Irving J., Wang Z., Powell S., O'Sullivan C., Mok M., Murphy B., Cardoza L., Lebkowski J.S. and Majumdar A.S., Conditionally replicative adenovirus driven by the human telomerase promoter provides broad-spectrum antitumor activity without liver toxicity. Cancer Gene Ther. 11: 174-185, 2004.

10. Lin T., Huang X., Gu J., Zhang L., Roth J.A., Xiong M., Curley S.A., Yu Y., Hunt K.K. and Fang B., Long-term tumor-free survival from treatment with the GFP-TRAIL fusion gene expressed from the hTERT promoter in breast cancer cells. Oncogene 21: 8020-8028, 2002.

11. Corey D.R., Telomerase inhibition, oligonucleotides, and clinical trials. Oncogene 21: 631-637, 2002.

12. Saretzki G., Telomerase inhibition as cancer therapy. Cancer Lett. 194: 209-219, 2003.

13. White L.K., Wright W.E. and Shay J.W., Telomerase inhibitors. Trends Biotechnol. 19: 114-120, 2001.

14. Kelland L.R., Overcoming the immortality of tumour cells by telomere and telomerase based cancer therapeuticscurrent status and future prospects. Eur. J. Cancer 41: 971979, 2005.

15. Gellert G.C., Dikmen Z.G., Wright W.E. and Shay J.W., Telomerase as a therapeutic target in cancer. Drug Disco. Today 2: 159-164, 2005.

16. Ku W.C., Cheng A.J. and Wang T.C., Inhibition of telomerase activity by PKC inhibitors in human nasopharyngeal cancer cells in culture. Biochem. Biophys. Res. Commun. 241: 730-736, 1997.

17. Li H., Zhao L., Yang Z., Funder J.W. and Liu J.P., Telomerase is controlled by protein kinase $\mathrm{C}-\alpha$ in human breast cancer cells. J. Biol. Chem. 273: 33436-33442, 1998.

18. Yu C.C., Lo S.C. and Wang T.C., Telomerase is regulated by protein kinase $\mathrm{C}-\zeta$ in human nasopharyngeal cancer cells. Biochem. J. 355: 459-464, 2001. 
19. Bodnar A.G., Kim N.M., Effros R.B. and Chin C.P., Mechanism of telomerase induction during $\mathrm{T}$ cell activation. Exp. Cell Res. 228: 58-64, 1996.

20. Igarashi H. and Sakaguchi N., Telomerase activity is induced by the stimulation to antigen receptor in human peripheral lymphocytes. Biochem. Biophys. Res. Commun. 219: 649-655, 1996.

21. Sheng W.Y., Chien Y.L. and Wang T.C., The dual role of protein kinase $\mathrm{C}$ in the regulation of telomerase activity in human lymphocytes. FEBS Lett. 540: 91-95, 2003.

22. Bleasdale J.E. and Fisher S.K., Use of U-73122 as an inhibitor of phospholipase C-dependent processes. Neuroprotocols 3: 125-133, 1993.

23. Cheng A.J., Tang R., Wang J.Y., Chang J.T. and Wang T.C., Polymerase chain reaction-based enzyme immunoassay for quantitation of telomerase activity: application to colorectal cancers. Jpn. J. Cancer Res. 90: 280-285, 1999.

24. Huang P.R., Yeh Y.M. and Wang T.C., Potent inhibition of human telomerase by helenalin. Cancer Lett. 227: 169174, 2005.

25. Huang Y.C., Haselbeck R.J., McAlister-Henn L. and Colman R.F., N-ethylmaleimide profiling of yeast NADP-dependent isocitrate dehydrogenase. Arch. Biochem. Biophys. 316: 485-492, 1995.

26. Mosbaugh D.W., Kunkel T.A., Stalker D.M., Tcheng J.E. and Meyer R.R., Novikoff hepatoma deoxyribonucleic acid polymerase. Sensitivity of the beta-polymerase to sulfhydryl blocking agents.. Nucleic Acids Res. 3: 2341-2352, 1976.

27. Krueger R.C., RNA elongation by RNA polymerase II is not inhibited by $N$-ethylmaleimide or iodoacetamide. Arch. Biochem. Biophys. 278: 475-477, 1990.

28. Andreola M.L., Tharaud D., Litvak S. and Tarrago-Litvak L., The ribonuclease $\mathrm{H}$ activity of HIV-1 reverse transcriptase: further biochemical characterization and search of inhibitors. Biochimie 75: 127-134, 1993.
29. Loya S. and Hizi A., The interaction of illimaquinone, a selective inhibitor of the RNase $\mathrm{H}$ activity, with the reverse transcriptases of human immunodeficiency and murine leukemia retroviruses. J. Biol. Chem. 268: $9323-$ 9328, 1993.

30. Bleasdale J.E., Thakur N.R., Gremban R.S., Bundy G.L., Fitzpatrick F.A., Smith R.J. and Bunting S., Selective inhibition of receptor-coupled phospholipase C-dependent processes in human platelets and polymorphonuclear neutrophils. J. Pharmacol. Exp. Ther. 255: 756-768, 1990.

31. Smith R.J., Sam L.M., Justen J.M., Bundy G.L., Bala G.A. and Bleasdale J.E., Receptor-coupled signal transduction in human polymorphonuclear neutrophils: effects of a novel inhibitor of phospholipase C-dependent processes on cell responsiveness. J. Pharmacol. Exp. Ther. 253: 688-697, 1990.

32. Zhang X., Mar V., Zhou W., Harrington L. and Robinson M.O., Telomere shortening and apoptosis in telomeraseinhibited human tumor cells. Genes Dev. 13: 2388-2399, 1999.

33. Hahn W.C., Stewart S.A., Brooks M.W., York S.G., Eaton E., Kurachi A., Beijersbergen R.L., Knoll J.H., Meyerson M. and Weinberg R.A., Inhibition of telomerase limits the growth of human cancer cells. Nat. Med. 5: 1164-1170, 1999.

34. Feng J., Funk W.D., Wang S.S., Weinrich S.L., Avilion A.A., Chiu C.P., Adams R.R., Chang E., Allsopp R.C., Yu J., Le M.D., West C.B., Harley W.H., Andrews D.W., Greider B. and Villeponteau B., The RNA component of human telomerase. Science 269: 1236-1241, 1995.

35. Li S., Rosenberg J.E., Donjacour A.A., Botchkina I.L., Hom Y.K., Cunha G.R. and Blackburn E.H., Rapid inhibition of cancer cell growth induced by lentiviral delivery and expression of mutant-template telomerase RNA and anti-telomerase short-interfering RNA. Cancer Res. 64: 4833-4840, 2004. 